\title{
Source Apportionment and Model Applicability of Heavy Metal Pollution in Farmland Soil Based on Three Receptor Models
}

Hong Liu

Zhejiang $A$ and $F$ University

Shiyan Liao

Zhejiang $A$ and $F$ University

Dongtao Wu

Lishui Agricultural and Rural Bureau

Gul Rukh

University of Peshawar

Zhenhua Chen

Jingning Agricultural and Rural Bureau,Lishui

Xiangdong Wu

Jingning Agricultural and Rural Bureau

Linlin Xiao

Zhejiang $A$ and $F$ University

Bin Zhong

Zhejiang $A$ and $F$ University

Dan Liu ( $\square$ liudan7812@aliyun.com )

Zhejiang A and F University

\section{Research Article}

Keywords: Heavy metals, Source apportionment, APCS-MLR, UNMIX, PMF.

Posted Date: November 30th, 2021

DOI: https://doi.org/10.21203/rs.3.rs-1103826/v1

License: (c) (i) This work is licensed under a Creative Commons Attribution 4.0 International License.

Read Full License 
1 Source apportionment and model applicability of heavy metal pollution in

2 farmland soil based on three receptor models

3 Hong Liu ${ }^{\mathrm{a}, 1}$, Shiyan Liao ${ }^{\mathrm{a}, 1}$, Dongtao $\mathrm{Wu}^{\mathrm{b}}$, Gul Rukh ${ }^{\mathrm{c}}$, Zhenhua Chen ${ }^{\mathrm{d}}$, Xiangdong Wu ${ }^{\mathrm{d}}$, Linlin

$4 \quad \mathrm{Xiao}^{\mathrm{a}}$, Bin Zhong ${ }^{\mathrm{a}}$, Dan Liu ${ }^{\mathrm{a}, *}$

5 a Key Laboratory of Soil Contamination Bioremediation of Zhejiang Province, Zhejiang A \& F University, Lin'an,

$7 \quad{ }^{\mathbf{b}}$ Lishui Agricultural and Rural Bureau, Lishui, 323000, China

${ }^{\mathbf{c}}$ Institute of Chemical Sciences, The University of Peshawar, Pakistan

d Jingning Agricultural and Rural Bureau, Lishui, 323000, China

*Corresponding author:

Dr. Dan Liu

\section{R. China}

Tel \& Fax: +86-571-63740889

E-mail: liudan7812@aliyun.com 
Abstract: The identification of the source of heavy metal pollution and its quantification are the prerequisite of soil pollution control. The APCS-MLR, UNMIX and PMF models were employed to apportion pollution sources of $\mathrm{Cu}, \mathrm{Zn}, \mathrm{Pb}, \mathrm{Cd}, \mathrm{Cr}$ and $\mathrm{Ni}$ of the farmland soil in vicinity of an abandoned iron and steel plant. The sources, contribution rates and applicability of the models were evaluated. The potential ecological risk index revealed greatest ecological risk from Cd. The results of source apportionment illustrated that APCS-MLR and UNMIX models can verify each other for accurate allocation of pollution sources. The industrial sources were the main sources of pollution (32.41\% 38.42\%), followed by agricultural sources $(29.35 \% \sim 31.65 \%)$, traffic emission sources $(21.03 \% \sim 21.51 \%)$, and natural sources of pollution were accounted for smallest proportion $(11.2 \%$ $\sim 14.42 \%)$. The PMF model was easily affected by outliers, its fitting degree was not ideal, and it was unable to get more accurate results of source analysis. The combination of multiple models can effectively improve accuracy of pollution source analysis of soil heavy metals. These results can provide a scientific basis for further remediation of heavy metal pollution in farmland soil.

Keywords: Heavy metals; Source apportionment; APCS-MLR; UNMIX; PMF.

\section{Introduction}

Soil is an important material basis for agricultural production and human survival(Drobnik et al., 2018). In recent decades, with gradual increase in population and rapid development of industry and agriculture, the problem of heavy metal pollution in farmland soil in China has become a crucial problem (Chen et al., 2008; Yang et al., 2017). Heavy metals in farmland soil are highly related to safety of agricultural products, which has attracted worldwide public attention (Chabukdhara and Nema, 2013; Shi et al., 2017). Heavy metals can not only threaten soil quality and ecological 
environment, but can accumulate in human body with transmission of food chain(Zhao et al., 2012; Guan et al., 2018). The measures should be taken to control and remediate heavy metal pollution in farmland soil, which is essential to ensure quality of soil environment and safety of agricultural products. Furthermore, assessment of the current status and sources of soil heavy metal pollution is a prerequisite for effective prevention of pollution.

Heavy metals in soil mainly originated from soil parent materials and human activities. Heavy metals contained in parent materials are enriched in the soil by weathering and leaching(Huang et al., 2015). Human activities mainly include high-intensity industrial and mining activities, agricultural activities and transportation, which contribute heavy metals to farmland soil through atmospheric deposition, sewage irrigation, fertilizer input and solid waste (Lu et al., 2014; Shi et al., 2018; Sun et al., 2019). Existing methods of source apportionment of heavy metals can be roughly divided in two categories, one is qualitative source identification, the other is quantitative source apportionment(Huang et al., 2018). The former mainly uses multivariate statistical analysis (principal component analysis, cluster analysis, correlation analysis, etc.) and geostatistical analysis to identify major pollution sources(Slavković et al., 2004; Luo et al., 2011; Yuan et al., 2015). The latter uses physical and chemical characteristics of pollutants in receptor to identify pollution source and to quantify its contribution rate(Huang et al., 2018).Among receptor models, absolute principal component scores-multivariate linear regression(APCS-MLR), UNMIX and positive matrix factorization (PMF) were widely used in source apportionment of heavy metals in soils(Lang et al., 2015; Bilal et al., 2019; Jin et al., 2019). APCS-MLR combines factor analysis and multiple linear regression to quantify pollution sources, with simple operation and fast calculation speed (Liu et al., 2019). The UNMIX model automatically removes unreasonable data through the system built in the 
model, and does not need to set the number and uncertainty of pollution sources, which reduces the impact of human factors(Ogundele et al., 2016). The PMF model limits the factor scores and factor loads to be non-negative during solution process, which can handle missing and inaccurate data ( $\mathrm{Lu}$ et al., 2018). The receptor models are widely used to perform source apportionment of atmosphere, water, sediment and soil(Fei et al., 2016; Ogundele et al., 2016; Sun et al., 2016; Chen et al., 2019). The research on source apportionment of heavy metals has mainly focused on analysis of potential pollution sources and their contributions in contaminated sites, but applicability of receptor models is rarely considered. Since soil is not a homogeneous body, it has a high degree of spatial heterogeneity(Zhang, 2006). The types, quantity and pollution status of pollution sources are different in different regions. The analytical results of receptor model are affected by factors such as sample data value errors and modeling errors, using a single receptor model which cannot obtain information of pollution source accurately, and its conclusion is controversial. Therefore, this study has employed several commonly used source analysis methods to analyze sources of heavy metals and to assess potential risks of heavy metals in farmland soils. The variation between validation models was compared and its causes were analyzed to accomplish more reliable results of source apportionment and to set a perfect foundation for prevention and control of heavy metal pollution in farmland soil.

The objectives of this study are: (1) to investigate the soil heavy metal pollution in the study area; (2) to analyze the sources and contributions of heavy metals in the study area by using APCS-MLR, UNMIX and PMF models, and compare the applicability of the models; (3) to evaluate the potential impact of heavy metal pollution in the study area in terms of ecological risk.

\section{Materials and methods}




\subsection{Study area}

The study area is located in the southeast of China, a town of Lishui City, Zhejiang Province. The study area covers an area of $2.12 \mathrm{~km}^{2}$, ranging from $119^{\circ} 42^{\prime} 44.7^{\prime \prime} \sim 119^{\circ} 42^{\prime} 5.5^{\prime \prime} \mathrm{E}$ and $27^{\circ} 46^{\prime} 50.6^{\prime \prime} \sim 27^{\circ} 47^{\prime} 54.3^{\prime \prime} \mathrm{N}$. The study area belongs to subtropical monsoon climate zone, with annual average temperature and precipitation of $17.8^{\circ} \mathrm{C}$ and $1568.4 \mathrm{~mm}$ respectively. The northeast wind prevails in the study area. The farmland in the study area is in vicinity of the township residential area. The waste steel plant is located in the south of the study area, and bamboo processing plant is in the east (Fig. 1). The farmland is terraced field, and the river flows from south to north. The water for farmland irrigation mainly comes from rainfall and river water pumping irrigation. The main crop in the study area is single cropping rice.

\subsection{Sample collection and preparation}

According to grid density of $50 \mathrm{~m} \times 50 \mathrm{~m}, 101$ surface soil samples $(0-20 \mathrm{~cm})$ were collected. Each soil sample was composed of 5 subsamples, one in the center and four in the surrounding area. The samples were put into PVC bags and coordinates of sampling points were recorded. The four soil profile samples were collected. The sampling point map is shown in Figure 1.The soil samples were air dried with natural conditions and visible intrusion of plants from samples were removed. The air dried soil samples were passed through a $2 \mathrm{~mm}$ aperture sieve. The grounded samples were passed through a 100 mesh sieve, and stored in sample bags. The soil $\mathrm{pH}$ was measured by $\mathrm{pH}$ meter with soil water ratio of 1:2.5. Soil organic matter ( $\mathrm{SOM})$ was determined by heating mixture of potassium dichromate and concentrated sulfuric acid at $180^{\circ} \mathrm{C}$, and then titrated with ferrous sulfate solution. The content of heavy metals was determined by $\mathrm{HF}(7 \mathrm{ml})-\mathrm{HNO}_{3}(5 \mathrm{ml})-\mathrm{HClO}_{3}(1 \mathrm{ml})$ mixed solution. After decocting, the samples were filtered with constant volume and stored for 
testing. The contents of copper $(\mathrm{Cu})$, zinc $(\mathrm{Zn})$, lead $(\mathrm{Pb})$, chromium $(\mathrm{Cr})$ and nickel $(\mathrm{Ni})$ were determined by inductively coupled plasma optical emission spectroscopy (ICP-OES, Leeman prodigy 7 USA). The cadmium (Cd) was analyzed by graphite furnace atomic absorption spectrometry (GFAAS, PerkinElmer AA800, USA). The accuracy of measurement was verified with Chinese Standard Reference Material (GSS-5). The recovery of each element was in the range of 90\%-110\%. The detection limits of $\mathrm{Cr}, \mathrm{Pb}, \mathrm{Cu}, \mathrm{Zn}, \mathrm{Ni}$, and $\mathrm{Cd}$ were $0.004,0.003,0.002,0.002$, 0.004 and $0.002 \mathrm{mg} / \mathrm{kg}$, respectively. All data are the average of three replicates.

\subsection{Source apportionment models}

\subsubsection{Absolute principal component scores-multivariate linear regression (APCS-MLR)}

The APCS-MLR was proposed by Thurston and Spengler in 1985. According to results of principal component analysis, the factor score was transformed to normalized factor score, and multiple linear regression was performed on receptor content. The contribution rate of pollution source corresponding to each factor of the substance in the receptor was calculated with regression coefficient as follows:

$$
\begin{gathered}
Z_{i j}=\frac{C_{i j}-\bar{C}_{l}}{\sigma_{i}} \\
\left(Z_{0}\right)_{i}=\frac{0-\bar{C}_{l}}{\sigma_{i}}=-\frac{\bar{C}_{l}}{\sigma_{i}} \\
A P C S_{p}=\left(Z_{0}\right)_{i}-Z_{i j} \\
C_{i}=b_{0 i}+\sum_{p=1}^{n}\left(A P C S_{p} \times b_{p i}\right)
\end{gathered}
$$

Where $C_{i j}$ is the content of heavy metal $i$ at the $j$ th sampling point; $\overline{C_{l}}$ is the mean content; $\sigma_{i}$ is the standard deviation; $Z_{i j}$ is normalization matrix of element content; $\left(Z_{0}\right)_{i}$ is the factor score of "zero" pollution point, where all element contents are equal to 0 . The principal component analysis was conducted for $Z_{i j}$ and $\left(Z_{0}\right)_{i}, p$ is the number of factors obtained in principal component 
analysis. The $A P C S_{p}$ is absolute principal component scores; $b_{0 i}$ is a constant term obtained by multiple linear regression for metal element $i$; $b_{p i}$ is the linear regression coefficient of element $i$ on factor $p$. The contribution of each source was calculated by $b_{p i}$ and $A P C S_{p}$.

\subsubsection{UNMIX model}

The UNMIX model is a receptor model developed by the U.S. Environmental Protection Agency. Based on the contribution of different pollution sources to receptor (soil), it is a linear combination of different source components(Henry, 2003). The equation is listed below:

$$
C_{i j}=\sum_{k=1}^{m} F_{j k} S_{j k}+E
$$

Where, the $C_{i j}$ is the content of heavy metal $i$ in the $j$ th sampling point, $F_{j k}$ is the percentage of element $j$ in the $k$ source, $S_{i k}$ is the contribution of $k$ source in sample $i$, and $E$ is the standard deviation of analysis. The source component spectrum parsed by model needs to meet minimum system requirements that can be interpreted by the model (Min Rsq $>0.8$, Min Sig/Noise $>2$ ).

UNMIX model was standardized before importing data to the model. The data were dimensionless and value range of observation value was between $0-1$. The standard formula of dispersion was as follows (Zhang et al., 2019):

$$
X_{k}=\frac{X_{i}-X_{i \min }}{X_{i \max }-X_{i \min }}
$$

Where $X_{k}$ is the value after deviation standardization, $X_{i}$ is the initial analysis value of the sample, $X_{i \min }$ is minimum analysis value, $X_{i \max }$ is maximum analysis value.

\subsubsection{Positive matrix factorization (PMF)}

PMF model is a multivariate factor analysis tool, which decomposes the receptor concentration data matrix into factor contribution matrix and factor distribution matrix under non negative constraint(Jiang et al., 2020). The goal of PMF is to analyze pollution sources and source 
145

contributions based on synthetic data sets(Lv, 2019). The calculation method is as follows:

$$
X_{i j}=\sum_{k=1}^{p} G_{i k} F_{k j}+E_{i j}
$$

Where: $X_{i j}$ is concentration matrix of the $j$ th heavy metal in the $i$ th sample; $G_{i k}$ is the contribution of the $k$ th source to sample $i ; F_{k j}$ is the value of the $k$ th source to concentration of heavy metal $j$, and $p$ is the number of factors; $E_{i j}$ is the residual.

The PMF model is defined and iterated on the basis of weighted least square method. The factor contribution and distribution were obtained by minimizing the objective function $\mathrm{Q}$ of the PMF model(Xue et al., 2014). The calculation method is as follows:

$$
Q=\sum_{i=1}^{n} \sum_{j=1}^{m}\left(\frac{E_{i j}}{U_{i j}}\right)^{2}
$$

Where $U_{i j}$ is uncertainty of element $j$ in sample $i$.

The PMF model was run with concentration data and uncertainty data. The uncertainty data includes sampling and analysis errors(Tan et al., 2016). In this study, the contents of $\mathrm{Cu}, \mathrm{Zn}, \mathrm{Pb}, \mathrm{Cd}$, $\mathrm{Cr}, \mathrm{Ni}$ in the soil were all higher than detection limit $M D L$. The calculation method of uncertainty Unc was as follows:

$$
U_{n c}=\sqrt{\left(\theta \times C_{i j}\right)^{2}+(M D L)^{2}}
$$

Where: $C_{i j}$ is concentration of heavy metal $i$ in the $j$ th sample; $M D L$ is the detection limit of the sample; $\theta$ is the relative standard deviation; signal to noise ratio $(\mathrm{S} / \mathrm{N})$ can be calculated by PMF, $\mathrm{S} / \mathrm{N}>2$ can be considered as good data quality, and the sample with $0.2<\mathrm{S} / \mathrm{N}<2$ can be considered as poor data quality, unable to provide sufficient concentration change(Sharma et al., 2016).

\subsection{Potential ecological risk index}

Potential ecological risk index $(R I)$ combines ecological and environmental effects of heavy 
metals with toxicology (Wu et al., 2018). The calculation formula for $R I$ is as follows:

$$
\begin{gathered}
E_{r}^{i}=T_{r}^{i} \times\left(\frac{C_{i}}{S_{i}}\right) \\
R I=\sum_{i}^{n} T_{r}^{i} \times\left(\frac{C_{i}}{S_{i}}\right)
\end{gathered}
$$

where $T_{r}^{i}$ is the biological toxicity of different elements $i$, which was determined as $\mathrm{Zn}=1<$ $\mathrm{Cr}=2<\mathrm{Cu}=\mathrm{Ni}=\mathrm{Pb}=5<\mathrm{Cd}=30$. The $C_{i}$ is measured value of heavy metal $i\left(\mathrm{mg} \cdot \mathrm{kg}^{-1}\right), S_{i}$ is the reference value of heavy metal $i$ in soil (background value in Zhejiang Province). $E_{r}^{i}$ represent potential ecological risk factors. $R I$ is the comprehensive potential ecological risk index of heavy metals. $E_{r}^{i}<40, R I<150$, indicates low potential ecological risk; $40 \leq E_{r}^{i}<80,150<R I<300$ indicate moderate potential ecological risk; $80 \leq E_{r}^{i}<160,300 \leq R I<600$ shows considerable potential ecological risk; $160 \leq E_{r}^{i}<320,600 \leq \mathrm{RI}<1200$ exhibit high potential ecological risk; $E_{r}^{i} \geq 320$, $R I \geq 1200$ reveal very high potential ecological risk.

\subsection{Data processing and statistical analysis}

The soil sampling points in the study area was located with ArcGIS 10.2; The descriptive analysis, correlation analysis and APCS-MLR model calculation was conducted with SPSS 22.0. The analysis chart was drawn with Oringin8.5. The source apportionment of heavy metals was determined with PMF model (EPA PMF 5.0) and UNMIX model (EPA UNMIX 6.0).

\section{Results and discussion}

\subsection{Descriptive statistical analysis of heavy metals in soil}

Table 1. reveals descriptive statistical analysis of heavy metal $(\mathrm{Cu}, \mathrm{Zn}, \mathrm{Pb}, \mathrm{Cd}, \mathrm{Cr}, \mathrm{Ni})$ and physical and chemical properties of farmland soil in the study area. The $\mathrm{pH}$ of soil acidic and ranged from 3.94 to 5.37. The mean contents of $\mathrm{Cu}, \mathrm{Zn}, \mathrm{Pb}, \mathrm{Cd}, \mathrm{Cr}$ and $\mathrm{Ni}$ were $30.26,271.50,151.41,0.37,67.81$ and $29.07 \mathrm{mg} \cdot \mathrm{kg}^{-1}$, respectively. The average contents of heavy 
metals in the study area were $1.72,3.85,6.39,5.33,1.28$ and 1.18 times of their background values respectively compared with background values of Zhejiang Province(Wang et al., 2007). The over standard rates of $\mathrm{Cu}, \mathrm{Zn}, \mathrm{Pb}, \mathrm{Cd}, \mathrm{Cr}$ and $\mathrm{Ni}$ in soil were $3.96 \%, 86.14 \%, 97.03 \%, 70.30 \%, 0 \%$, $0.99 \%$, respectively compared with screening values of agricultural soil environmental risks in China (GB 15618-2018). The coefficient of variation (CV) reflect variability and dispersion of heavy metal elements in soil. The strong variability indicates that spatial distribution of heavy metals was seriously affected by external factors (McGrath et al., 2003; Gallardo and Paramá, 2007). The CVs of heavy metals can be classified as follows: $\mathrm{CV} \leq 15 \%$ means weak variation, $15 \%<\mathrm{CV}<36 \%$ means moderate variation, $\mathrm{CV} \geq 36 \%$ means high variation. The $\mathrm{CV}$ of $\mathrm{Pb}, \mathrm{Cd}$, $\mathrm{Ni}$ in the study area were $38.5 \%, 40.17 \%, 39.03 \%$, which indicate high variation. The elements of other heavy metals showed moderate variation, which showed that external factors had a significant impact on accumulation of heavy metals in soil.

\subsection{Heavy metal content in soil profile}

Four profiles were collected in the study area. Fig2. demonstrates depth distribution of soil $\mathrm{pH}$, organic matter $(\mathrm{OM})$ and heavy metals in soil profiles. The $\mathrm{pH}$ value of surface $(0-20 \mathrm{~cm})$ soil was lowest compared with highest of bottom $(60-80 \mathrm{~cm})$ soil. Excessive use of nitrogen fertilizer has led to serious acidification of agricultural soil in China. The nitrogen fertilizer has been identified as the main driving force of acidification in farmland soil by affecting process of nitrogen transformation ( Hao et al., 2020). The content of SOM in topsoil was highest and decreased with increase of depth, which was mainly attributed to application of fertilizer in farmland soil and popularization of straw returning technology(PAN et al., 2004; Xiao-Lin et al., 2021). The contents of $\mathrm{Cu}, \mathrm{Zn}, \mathrm{Pb}, \mathrm{Cd}$ and $\mathrm{Ni}$ in surface soil were significantly higher than deep soil $(40-60 \mathrm{~cm})$ and bottom soil $(60-80 \mathrm{~cm})$ 
soil, which indicated that these heavy metals were greatly affected by input of external activities. The content of $\mathrm{Cr}$ in the bottom $(60-80 \mathrm{~cm})$ soil was significantly higher than surface soil $(0-20 \mathrm{~cm})$, which indicated that $\mathrm{Cr}$ was mainly affected by soil parent material. The contents of SOM and $\mathrm{Cu}$ in P3 were significantly higher than other three sections which illustrated that the area was greatly affected by agricultural activities. However, the $\mathrm{Zn}$ and $\mathrm{Pb}$ contents in $\mathrm{P} 1$ were significantly higher than other three sections, which has confirmed the sources of potential heavy metal pollution in this area.

\subsection{Results of three models}

The source distribution of heavy metals in the study area was analyzed with APCS-MLR, UNMIX and PMF models. The APCS-MLR has extracted four factors, which accounted for $88.58 \%$ of the data variance. The explained variances were $25.13 \%, 25.0 \%, 20.91 \%$ and $17.6 \%$ respectively. The PMF model has set the number of factors $4 \sim 7$ and the number of runs was 20 . The optimal number of factors was finally determined to be 4 after comprehensive trial calculation of $\mathrm{Q}$ value. The UNMIX model resolves 4 factors, among which Min Rsq=0.95, Min Sig/Noise=2.03, which meets minimum value required by the system (Min Rsq $>0.8$, Min Sig/Noise $>2$ ).

Fig. 3(a, b, c) exhibits composition of factors was analyzed by APCS-MLR, PMF and UNMIX models. The factor components of APCS-MLR and UNMIX model were similar. In factor 1, Cu and Ni had higher loads. Factor 2 was $\mathrm{Cd}$ and $\mathrm{Zn}$, factor 3 was $\mathrm{Pb}$, and factor 4 was $\mathrm{Cr}$. In addition, the fitted parameters with three models were described in Table 2. The minimum value of $\mathrm{r}^{2} \mathrm{was} \mathrm{Cu}$ (0.79) in APCS-MLR, and $\mathrm{r}^{2}$ of the other heavy metal elements was greater than 0.8 both in APCSMLR and UNMIX, which reveals ideal fitness of the two models. In PMF model, the factor composition was quite different from APCS-MLR and UNMIX. The Factor 1 was dominated by $\mathrm{Cu}$, 
$\mathrm{Zn}, \mathrm{Pb}, \mathrm{Cd}, \mathrm{Ni}$, factor 2 was $\mathrm{Cu}, \mathrm{Zn}, \mathrm{Pb}, \mathrm{Cr}$, Ni, factor 3 was $\mathrm{Cd}$, and factor 4 was $\mathrm{Cr}$., The $\mathrm{r}^{2}$ between predicted and observed values of $\mathrm{Cu}, \mathrm{Cd}$ and $\mathrm{Ni}$ in PMF was close to 1 according to components fitting results (Table 2). The $\mathrm{r}^{2}$ of $\mathrm{Zn}, \mathrm{Pb}$ and $\mathrm{Cr}$ were $0.402,0.119$ and 0.403 respectively however, fitness of results was not ideal. The studies revealed that PMF model was abnormally sensitive to outliers, and can not acquire reasonable results without elimination of outliers.

The 13 sampling points were deleted according to unified residual value of each point until $Q_{\text {robust }}$ and $Q_{\text {ture }}$ were in proximity to unreliable results of source analysis using complete data in PMF. Four factors were obtained in PMF, the factor composition was presented in Figure 3 (d)., The proportion of factor 1 in each heavy metal element increases compared with complete data, while proportion of factor 3 decreases after excluding abnormal values. The fitness of the model has improved, $\mathrm{r}^{2}$ values of $\mathrm{Zn}, \mathrm{Pb}$, and $\mathrm{Cr}$ and its observed $\mathrm{r}^{2}$ values were $0.448,0.213$, and 0.61 , respectively. However, no more reliable fitting results were obtained, which was consistent with results of Xue et al(Xue et al., 2014).

\subsection{Source apportionment of heavy metals in soil}

The composition of pollution sources of APCS-MLR and UNMIX models were similar. In the composition spectrum of factor 1 (Fig.3), the load of $\mathrm{Cu}$ and $\mathrm{Ni}$ was higher than other elements. The $\mathrm{Zn}, \mathrm{Pb}, \mathrm{Cd}$ and $\mathrm{Cr}$ were distributed in a small amount. The studies reported that human activities could significantly change spatial characteristics of $\mathrm{Ni}$ in soil, and diffusion of $\mathrm{Ni}$ in environment was mainly affected by atmospheric deposition and sewage irrigation(Li et al., 2009; Huang et al., 2019). In industrial enterprises, iron and steel plant was a significant source of heavy metal pollution. In the past few decades, due to lack of environmental protection technology to address the dust and waste produced in the iron and steel smelting process, the $\mathrm{Cu}$ content in the surrounding soil was 5 
times higher than background value(Orescanin et al., 2004). The study of heavy metal content in soil near a steel plant in Serbia showed that concentrations of $\mathrm{Cd}, \mathrm{Cu}, \mathrm{Ni}, \mathrm{Pb}$ and $\mathrm{Zn}$ were higher than reported in European soils and higher than world average(Dragović et al., 2014). The abandoned iron and steel plant was located in the north of the study area, in the upper reaches of the river, and the terrain was higher than farmland. Dust and sewage generated in the process of steel smelting and processing were accumulated in soil with atmospheric sedimentation, rain erosion and farmland irrigation. Therefore, factor 1 represented industrial pollution source.

In factor 2, the calculation results of APCS-MLR and UNMIX models suggested that $\mathrm{Cd}$ and $\mathrm{Zn}$ were marker elements (Fig. 3a, b). Pearson correlation analysis results of heavy metal content and physical and chemical properties in soil are reported in table 3.SOM has significant correlation with $\mathrm{Cd}$ and $\mathrm{Zn}$ at $\mathrm{P}<0.05$, and its correlation coefficients were 0.487 and 0.437 , respectively. As discussed in the previous sections, Cd usually exists in phosphate rock, and as chemical fertilizers, especially phosphate fertilizers, were brought to farmland soil(Lu et al., 2012). The $\mathrm{Zn}$ was widely used in livestock feed as additives, which was excreted out of the body with feces(Yang et al., 2016). Long term application of chemical fertilizer, organic fertilizer and animal manure in agricultural activities will enhance concentration of $\mathrm{Zn}$ and $\mathrm{Cd}$ in soil. (Bigalke et al., 2017; Zhuang et al., 2020). According to field survey, the farmers bred livestock and poultry directly in the farmland after harvest, which transferred heavy metals to soil from manure of livestock. In addition, this was an important reason why the content of SOM in this study was significantly higher than average level of Zhejiang Province. Accordingly, factor 2 could be identified as agricultural source.

Factor 3 represent transportation which is major cause of pollution due to $\mathrm{Pb}, \mathrm{Cu}$ and $\mathrm{Zn}$. Due to combustion of fuels and use of engine catalysts, $\mathrm{Pb}$ was main indicator of traffic emissions(Xiao et 
271

272

273

al., 2019; Wang et al., 2020). Although the production, sale and use of leaded gasoline have been banned since 2000, the accumulation of $\mathrm{Pb}$ in soil has not been eliminated (Chen et al., 2016). The $\mathrm{Cu}$ is usually used in metal parts of automobiles. The $\mathrm{Zn}$ in surface soils is related to wearing of tires and corrosion of galvanized parts(Smichowski et al., 2008; Cai et al., 2019). In this study area, a large number of farmland is distributed along the road. The major cause of $\mathrm{Pb}, \mathrm{Cu}$ and $\mathrm{Zn}$ pollution of farmland soil was due to road dust. Furthermore, in profile 1(Fig.2), the $\mathrm{Pb}$ content in topsoil was significantly higher than other three sections of soil. The heavy metal $(\mathrm{Pb})$ in the soil was enriched by intensive transportation. In factor 4, the ratios of Cr determined by APCS-MLR and UNMIX models accounted for $79.75 \%$ and $93.37 \%$ of the total, respectively. The concentration of $\mathrm{Cr}$ in the study area was significantly lower than background value. According to the soil profile analysis (Fig. 2), $\mathrm{Cr}$ in the soil originated from parent material, which had been verified in previous studies (Franco-Uría et al., 2009; Cai et al., 2012). Therefore, factor 4 represents natural sources.

In the PMF-1 model, the main elements in factor 1 were $\mathrm{Cr}$ and $\mathrm{Cu}$, but $\mathrm{Zn}, \mathrm{Pb}$ and $\mathrm{Ni}$ have large loads; in PMF-2, the proportion of heavy metal elements in factor 1 was significantly increased, which indicated that due to calculation of PMF, the natural source accounts for large proportion, so factor 1 is the natural source. In factor 2 of PMF-1, $\mathrm{Cu}$ and $\mathrm{Ni}$ account for large proportion, representing industrial pollution sources; PMF-2 subdivides industrial pollution sources in factor 2 and factor 3. Factor 2 represents atmospheric deposition pollution source, and factor 3 represents irrigation water pollution source. Previous studies on heavy metal input flux of farmland soil reported that input percentage of $\mathrm{Cr}$ from atmospheric deposition was highest, followed by irrigation. The percentage of Ni entering farmland through irrigation was highest(Chen et al., 2018). In PMF1, the main elements in factor 3 was $\mathrm{Cd}, \mathrm{Cu}, \mathrm{Zn}$ and $\mathrm{Pb}$, in which $\mathrm{Cd}, \mathrm{Cu}, \mathrm{Zn}$ were significantly 
correlated with $\mathrm{SOM}$ content, and $\mathrm{Pb}$ was main indicator of traffic emission., The factor 3 was mixed pollution source of organic fertilizer input and traffic emission. The main element of factor 4 was $\mathrm{Cd}$, mainly from chemical fertilizer. In PMF-2, the main elements in factor 4 were $\mathrm{Cd}$ and $\mathrm{Zn}$, which were the comprehensive sources of organic fertilizer and chemical fertilizer.

\subsection{Source contribution analysis}

, The contribution of each pollution source as calculated by three models of APCS-MLR, PMF and UNMIX is demonstrated in Fig.4. The proportions of industrial sources, agricultural sources, traffic emission sources, and natural sources in the APCS-MLR model are 32.41\%, 31.65\%, 21.51\% and $14.42 \%$ respectively. The proportions of the above four sources are $38.42 \% .29 .35 \%, 21.03 \%$, $11.2 \%$ in UNMIX model. The contributions of natural sources, industrial sources, mixed sources of organic fertilizer and traffic emissions, and chemical fertilizer sources are 41.88\%, 27.7\%, 20.35\% and $10.06 \%$ respectively in PMF- 1 . The contribution rates of natural sources, atmospheric deposition, irrigation and fertilizer sources are $48.84 \%, 22.47 \%, 13.78 \%$ and $14.91 \%$ respectively in PMF-2.

According to contribution rate of three models, the results of APCS-MLR and UNMIX model are consistent. The composition and contribution of pollution sources are highly similar, which indicates that results of source apportionment are reliable. The natural sources account for largest proportion in PMF model. Except Cr, other elements in factor 1 have high load. The correlation analysis indicates that $\mathrm{Cr}$ is significantly correlated with $\mathrm{Cu}(\mathrm{P}<0.05)$, and correlated with $\mathrm{Ni}(\mathrm{P}<0.1)$. Which indicated that $\mathrm{Cr}, \mathrm{Cu}$ and $\mathrm{Ni}$ have common sources. The $\mathrm{Zn}$ and $\mathrm{Pb}$ in factor 1 are from other pollution sources. It was observed that the fitting effect of $\mathrm{Zn}$ and $\mathrm{Pb}$ is the worst in the PMF model analysis process (table 2), which may be due to wide sources of $\mathrm{Zn}$ and $\mathrm{Pb}$ in the study area and its 
315 high content in the soil. Several areas were interfered by a variety of pollution sources with high

316 intensity and long pollution time, due to which PMF model was unable to accurately identify their

317 pollution sources. The proportion of natural sources in PMF model increased significantly after

318 elimination of outliers, which indicated that PMF model is very sensitive to outliers. The

319 contribution of corresponding pollution sources will be underestimated after exclusion of outliers.

320 The PMF model will minimize Q value of the objective function if outliers are retained. The model

321 itself will give priority to fitting of outliers., As a result, the factor contribution tends to outliers, and

322 accurate source analysis data can not be obtained. Therefore, influence of outliers on analytical

323 results of PMF model should be carefully considered in the selection of receptor model.

\subsection{Evaluation of potential ecological risk index}

area (table 4). The results showed that average risk index of heavy metals in the soil of the study

area was $\mathrm{Cd}(160.01)>\mathrm{Pb}(31.94)>\mathrm{Ni}(10.69)>\mathrm{Cu}(8.60)>\mathrm{Zn}(3.85)>\mathrm{Cr}(2.56)$. The mean value

of $\mathrm{Cd}$ indicated a strong ecological risk degree, and $\mathrm{Cd}$ showed a very strong risk degree in a few

sampling points. The comprehensive potential ecological risk index ranged from 92.37 to 489.68 ,

with an average value of 217.65. There was a large difference in the risk level, and overall risk level

was medium. The contribution of $\mathrm{Cd}$ to comprehensive potential ecological risk was $73.52 \%$, which was the main source of potential ecological risk of heavy metals in the study area.

\section{Conclusion}

334 The pollution of heavy metals $\mathrm{Pb}, \mathrm{Zn}$ and $\mathrm{Cd}$ in farmland soil is more serious due to rapid development of industry and agriculture. The $\mathrm{Cu}, \mathrm{Zn}, \mathrm{Pb}, \mathrm{Cd}$ and $\mathrm{Ni}$ were enriched in topsoil, while 
was the main element causing risk of heavy metal pollution in the region. The sources of heavy metals in soil were analyzed with APCS-MLR, UNMIX and PMF models. The industrial sources, agricultural sources, traffic emission sources and natural sources accounted for $32.41 \%$ (38.42\%), $31.65 \%(29.35 \%), 21.51 \%(21.03 \%)$ and $14.42 \%(11.2 \%)$ respectively. These two models can better explain the source and contribution of heavy metal pollution in soil, and are more appropriate for this kind of study. However, the PMF model can be easily affected by outliers, and the fitting effect of $\mathrm{Zn}$ and $\mathrm{Pb}$ is not ideal, which leads to its high proportion in natural sources, which reduces credibility of source apportionment results. The APCS-MLR and UNMIX models are more appropriate for this study. According to potential ecological risk index, $\mathrm{Cd}$ has greatest ecological risk. Therefore, in the process of soil pollution control, priority should be given to control the harm of $\mathrm{Cd}$ to local ecological environment. The receptor model should be carefully selected in the process of soil heavy metal source apportionment. The comprehensive application of multiple models can facilitate improvement in reliability of source apportionment results.

\section{Funding}

This work was supported by a grant from Natural Science Foundation of China (31670617) and Natural Science Foundation of Zhejiang province (LZ20C160003).

\section{Declaration of interests}

The authors declare that they have no known competing financial interests or personal relationships that could have appeared to influence the work reported in this paper.

\section{Data availability}

The authors confirm that the data and materials supporting the findings of this study are available within the article. 


\section{Author contribution}

Under the supervision of Liu Dan, Hong Liu and Shiyan Liao performed sample preparation

361 and data analysis, wrote the first draft. Gul Rukh reviewed and edited the writing. Dongtao $\mathrm{Wu}$,

362 Xiangdong $\mathrm{Wu}$ and Zhenhua Chen managed the project. Linlin Xiao and Bin Zhong carried out

363 sample preparation and experimental operation. All authors read and contributed to the manuscript.

$364 \quad$ Animal research

$365 \quad$ No animals were used in this experiment.

\section{Consent to Participate and Consent to Publish}

367 Informed consent was obtained from all individual participants included in the study. 


\section{References}

Bigalke M, Ulrich A, Rehmus A, Keller A (2017). Accumulation of cadmium and uranium in arable soils in Switzerland. Environmental Pollution, 221: 85-93. https://doi.org/10.1016/j.envpol.2016.11.035

Bilal I, Abdugheni A, Qingdong S, Suhong L, Li H (2019). Quantitatively assessing the risks and possible sources of toxic metals in soil from an arid, coal-dependent industrial region in NW China. Journal of Geochemical Exploration, 212: 106505. https://doi.org/10.1016/j.gexplo.2020.106505

Cai L-M, Wang Q-S, Wen H-H, Luo J, Wang S (2019). Heavy metals in agricultural soils from a typical township in Guangdong Province, China: Occurrences and spatial distribution. Ecotoxicology and Environmental Safety, 164-191. https://doi.org/10.1016/j.ecoenv.2018.10.092

Cai L, Xu Z, Ren M, Guo Q, Hu X, Hu G, Wan H, Peng P (2012). Source identification of eight hazardous heavy metals in agricultural soils of Huizhou, Guangdong Province, China. Ecotoxicology and Environmental Safety, 78

Chabukdhara M, Nema A K (2013). Heavy metals assessment in urban soil around industrial clusters in Ghaziabad, India: Probabilistic health risk approach. Ecotoxicology and Environmental Safety, 87: 57-64. https://doi.org/10.1016/j.ecoenv.2012.08.032

Chen L, Zhou S, Wu S, Wang C, Li B, Li Y, Wang J (2018). Combining emission inventory and isotope ratio analyses for quantitative source apportionment of heavy metals in agricultural soil. Chemosphere, 204: 140-147. https://doi.org/10.1016/j.chemosphere.2018.04.002

Chen R, Chen H, Song L, Yao Z, Meng F, Teng Y (2019). Characterization and source apportionment of heavy metals in the sediments of Lake Tai (China) and its surrounding soils. Science of the Total Environment, 694: 133819. https://doi.org/10.1016/j.scitotenv.2019.133819

Chen T, Chang Q, Liu J, Clevers J G P W, Kooistra L (2016). Identification of soil heavy metal sources and improvement in spatial mapping based on soil spectral information: A case study in northwest China. Science of the Total Environment, 565:155-164. https://doi.org/10.1016/j.scitotenv.2016.04.163

Chen T, Liu X, Li X, Zhao K, Zhang J, Xu J, Shi J, Dahlgren R A (2008). Heavy metal sources identification and sampling uncertainty analysis in a field-scale vegetable soil of Hangzhou, $\begin{array}{lll}\text { China. } & \text { Environmental 1003-1010. }\end{array}$ https://doi.org/10.1016/j.envpol.2008.10.011

Dragović R, Gajić B, Dragović S, Đorđević M, Đorđević M, Mihailović N, Onjia A (2014). Assessment of the impact of geographical factors on the spatial distribution of heavy metals in soils around the steel production facility in Smederevo (Serbia). Journal of Cleaner Production, 84: $550-562$.

Drobnik T, Greiner L, Keller A, Grêt-Regamey A (2018). Soil quality indicators-From soil functions to ecosystem services. Ecological indicators, 94: 151-169. 
https://doi.org/10.1016/j.ecolind.2018.06.052

Fei L, Chan L Y, Bi X, Guo H, Liu Y, Lin Q, Wang X, Peng P A, Sheng G (2016). Effect of cloudto-ground lightning and meteorological conditions on surface NOx and O3 in Hong Kong. Atmospheric Research, 182: 132-141. https://doi.org/10.1016/j.atmosres.2016.07.021

Franco-Uría A, López-Mateo C, Roca E, Fernández-Marcos M L (2009). Source identification of heavy metals in pastureland by multivariate analysis in NW Spain. Journal of hazardous materials, 165(1-3): 1008-1015. https://doi.org/10.1016/j.jhazmat.2008.10.118

Gallardo A, Paramá R (2007). Spatial variability of soil elements in two plant communities of NW Spain. Geoderma, 139(1): 199-208. https://doi.org/10.1016/j.geoderma.2007.01.022

Guan Q, Wang F, Xu C, Pan N, Lin J, Zhao R, Yang Y, Luo H (2018). Source apportionment of heavy metals in agricultural soil based on PMF: A case study in Hexi Corridor, northwest China. Chemosphere, 193: 189-197. https://doi.org/10.1016/j.chemosphere.2017.10.151

Hao T, Zhu Q, Zeng M, Shen J, Shi X, Liu X, Zhang F, Vries W D (2020). Impacts of nitrogen fertilizer type and application rate on soil acidification rate under a wheat-maize double cropping system. Journal of environmental management, 270

Henry R C (2003). Multivariate receptor modeling by N-dimensional edge detection. Chemometrics and intelligent laboratory systems, 65(2): 179-189. https://doi.org/10.1016/S01697439(02)00108-9

Huang J, Peng S, Mao X, Li F, Guo S, Shi L, Shi Y, Yu H, Zeng G-M (2019). Source apportionment and spatial and quantitative ecological risk assessment of heavy metals in soils from a typical Chinese agricultural county. Process Safety and Environmental Protection, 126:339-347. https://doi.org/10.1016/j.psep.2019.04.023

Huang Y, Deng M, Wu S, Japenga J, Li T, Yang X, He Z (2018). A modified receptor model for source apportionment of heavy metal pollution in soil. Journal of hazardous materials, 354 : 161-169. https://10.1016/j.jhazmat.2018.05.006

Huang Y, Li T, Wu C, He Z, Japenga J, Deng M, Yang X (2015). An integrated approach to assess heavy metal source apportionment in peri-urban agricultural soils. Journal of hazardous materials, 299: 540-549. https://doi.org/10.1016/j.jhazmat.2015.07.041

Jiang H-H, Cai L-M, Wen H-H, Hu G-C, Chen L-G, Luo J (2020). An integrated approach to quantifying ecological and human health risks from different sources of soil heavy metals. $\begin{array}{llll}\text { Science of the Total } & 134466 .\end{array}$ https://doi.org/10.1016/j.scitotenv.2019.134466

Jin G, Fang W, Shafi M, Wu D, Li Y, Zhong B, Ma J, Liu D (2019). Source apportionment of heavy metals in farmland soil with application of APCS-MLR model: A pilot study for restoration of farmland in Shaoxing City Zhejiang, China. Ecotoxicology and Environmental Safety, 184: 109495. https://10.1016/j.ecoenv.2019.109495

Lang Y, Li G, Wang X, Peng P, Bai J (2015). Combination of Unmix and positive matrix factorization model identifying contributions to carcinogenicity and mutagenicity for 
polycyclic aromatic hydrocarbons sources in Liaohe delta reed wetland soils, China. Chemosphere, 120:431-437.

Li J, He M, Han W, Gu Y (2009). Analysis and assessment on heavy metal sources in the coastal soils developed from alluvial deposits using multivariate statistical methods. Journal of hazardous materials, 164(2-3): 976-981. https://doi.org/10.1016/j.jhazmat.2008.08.112

Liu L, Tang Z, Kong M, Chen X, Zhou C, Huang K, Wang Z (2019). Tracing the potential pollution sources of the coastal water in Hong Kong with statistical models combining APCS-MLR. Journal of environmental

management, 245:143-150. https://doi.org/10.1016/j.jenvman.2019.05.066

Lu A, Wang J, Qin X, Wang K, Han P, Zhang S (2012). Multivariate and geostatistical analyses of the spatial distribution and origin of heavy metals in the agricultural soils in Shunyi, Beijing, China. Science of the Total Environment, 425:66-74. https://doi.org/10.1016/j.scitotenv.2012.03.003

Lu S, XiaoY L, X L Y, G Z, Dong M (2014). Evaluation of heavy metal and polycyclic aromatic hydrocarbons accumulation in plants from typical industrial sites: potential candidate in phytoremediation for co-contamination. Environmental science and pollution research international, 21(21):12494-12504.

Lu Z, Liu Q, Xiong Y, Huang F, Zhou J, Schauer J J (2018). A hybrid source apportionment strategy using positive matrix factorization (PMF) and molecular marker chemical mass balance (MMCMB) models. Environmental Pollution, 238:39-51. https://doi.org/10.1016/j.envpol.2018.02.091

Luo X-S, Yu S, Li X-D (2011). Distribution, availability, and sources of trace metals in different particle size fractions of urban soils in Hong Kong: Implications for assessing the risk to human $\begin{array}{llll}\text { health. } & \text { Environmental 159(5):1317-1326. }\end{array}$ https://doi.org/10.1016/j.envpol.2011.01.013

Lv J (2019). Multivariate receptor models and robust geostatistics to estimate source apportionment of heavy metals in soils. Environmental pollution, 244:72-83. https://doi.org/10.1016/j.envpol.2018.09.147

Mcgrath D, Zhang C, Carton O T (2003). Geostatistical analyses and hazard assessment on soil lead in Silvermines area, Ireland. Environmental Pollution, 127(2):239-248. https://doi.org/10.1016/j.envpol.2003.07.002

Ogundele L T, Owoade O K, Olise F S, Hopke P K (2016). Source identification and apportionment of PM2.5 and PM2.5-10 in iron and steel scrap smelting factory environment using PMF, PCFA and UNMIX receptor models. Environmental monitoring and assessment, 188(10):574. https://doi.org/10.1007/s10661-016-5585-8

Orescanin V, Barisic D, Mikelic L, Lovrencic I, Rubcic M, Rozmaric-Macefat M, Lulic S (2004). Environmental contamination assessment of the surroundings of the ex-Sibenik's ferromanganese smelter, Croatia. Journal of Environmental Science \& Health Part A 
Toxic/hazardous Substances \& Environmental Engineering, 39(9): 2493-2506. https://doi.org/10.1081/ESE-200026329

Pan G-X, Li L-Q, Zhang Q, Wang X-K, Sun X-B, Xu X-B, Jiang D-A (2004). Organic carbon stock in topsoil of Jiangsu Province, China, andthe recent trend of carbon sequestration. Journal of Environmental Sciences, 17(1):1-7.

Sharma S K, Sharma A, Saxena M, Choudhary N, Masiwal R, Mandal T K, Sharma C (2016). Chemical characterization and source apportionment of aerosol at an urban area of Central Delhi, India. Atmospheric Pollution Research, 7(1): 110-121. https://doi.org/10.1016/j.apr.2015.08.002

Shi T, Ma J, Wu X, Ju T, Lin X, Zhang Y, Li X, Gong Y, Hou H, Zhao L, Wu F (2018). Inventories of heavy metal inputs and outputs to and from agricultural soils: A review. Ecotoxicology and Environmental Safety, 164:118-124. https://doi.org/10.1016/j.ecoenv.2018.08.016

Shi Y, Huang J, Zeng G, Gu Y, Chen Y, Hu Y, Tang B, Zhou J, Yang Y, Shi L (2017). Exploiting extracellular polymeric substances (EPS) controlling strategies for performance enhancement of biological wastewater treatments: An overview. Chemosphere, 180. https://10.1016/j.chemosphere.2017.04.042

Slavković L, Škrbić B, Miljević N, Onjia A (2004). Principal component analysis of trace elements in industrial soils. Environmental Chemistry Letters, 2(2):105-108. https://doi.org/10.1007/s10311-004-0073-8

Smichowski P, Gomez D, Frazzoli C, Caroli S (2008). Traffic-Related Elements in Airborne Particulate Matter. Applied Spectroscopy Reviews, 43(1). https://doi.org/10.1080/05704920701645886

Sun L, Guo D, Liu K, Meng H, Zheng Y, Yuan F, Zhu G (2019). Levels, sources, and spatial distribution of heavy metals in soils from a typical coal industrial city of Tangshan, China. Catena, 175:101-109. https://doi.org/10.1016/j.catena.2018.12.014

Sun L, Peng W, Cheng C (2016). Source estimating of heavy metals in shallow groundwater based on UNMIX model: A case study. Indian Journal of Marine Sciences, 45(6): 756-762.

Tan J, Duan J, Ma Y, He K, Cheng Y, Deng S-X, Huang Y-L, Si-Tu S-P (2016). Long-term trends of chemical characteristics and sources of fine particle in Foshan City, Pearl River Delta: 20082014. Science of the Total Environment, 565:519-528.

Wang Q, Dong Y, Zhou G, Zheng W (2007). Soil geochemical baseline and environmental background values of agricultural regions in Zhejiang Province. Journal of Ecology and Rural Environment, 2007(02): 81-88.

Wang Y, Zhang L, Wang J, Lv J (2020). Identifying quantitative sources and spatial distributions of potentially toxic elements in soils by using three receptor models and sequential indicator simulation. Chemosphere, 242:125266. https://doi.org/10.1016/j.chemosphere.2019.125266

Wu J, Lu J, Li L, Min X, Luo Y (2018). Pollution, ecological-health risks, and sources of heavy metals in soil of the northeastern Qinghai-Tibet Plateau. Chemosphere, 201: 234-242. 
https://10.1016/j.chemosphere.2018.02.122

Xiao L S, Budiman M, Hui-Li W, Yu-Guo Z, Gan-Lin Z, Yun-Jin W (2021). Spatiotemporal modelling of soil organic matter changes in Jiangsu, China between 1980 and 2006 using INLA-SPDE. Geoderma, 384

Xiao R, Guo D, Ali A, Mi S, Liu T, Ren C, Li R, Zhang Z (2019). Accumulation, ecological-health risks assessment, and source apportionment of heavy metals in paddy soils: A case study in Hanzhong, Shaanxi, China. Environmental Pollution, 248:349-357.

Xue J L, Zhi Y Y, Yang L P, Shi J C, Zeng L Z, Wu L-S (2014). Positive matrix factorization as source apportionment of soil lead and cadmium around a battery plant (Changxing County, China). Environmental Science and Pollution Research, 21(12): 7698-7707. https://doi.org/10.1007/s11356-014-2726-X

Yang Y, Chen W, Wang M, Peng C (2016). Regional accumulation characteristics of cadmium in vegetables: Influencing factors, transfer model and indication of soil threshold content. Environmental Pollution, 219:1036-1043. https://doi.org/10.1016/j.envpol.2016.09.003

Yang Y, Christakos G, Guo M, Xiao L, Huang W (2017). Space-time quantitative source apportionment of soil heavy metal concentration increments. Environmental Pollution, 223:560-566. https://doi.org/10.1016/j.envpol.2017.01.058

Yuan C, Jia G, Sheli C, Jing C, Linfu X, Qingwei Z (2015). Source identification of eight heavy metals in grassland soils by multivariate analysis from the Baicheng-Songyuan area, Jilin Province, Northeast China. 134:67-75. https://doi.org/10.1016/j.chemosphere.2015.04.008

Zhang C (2006). Using multivariate analyses and GIS to identify pollutants and their spatial patterns in urban soils in Galway, Ireland. Environmental pollution, 42(3):501-511. https://doi.org/10.1016/j.envpol.2005.10.028

Zhang S, Wang L, Zhang W, Wang L, Shi X, Lu X, Li X (2019). Pollution Assessment and Source Apportionment of Trace Metals in Urban Topsoil of Xi' an City in Northwest China. Archives of environmental contamination and toxicology, 77(4): 575-586.

Zhao H, Xia B, Fan C, Zhao P, Shen S (2012). Human health risk from soil heavy metal contamination under different land uses near Dabaoshan Mine, Southern China. Science of the Total Environment, 417-418: 45-54. https://doi.org/10.1016/j.scitotenv.2011.12.047

Zhuang Z, Mu H-Y, Fu P-N, Wan Y-N, Yu Y, Wang Q, Li H-F (2020). Accumulation of potentially toxic elements in agricultural soil and scenario analysis of cadmium inputs by fertilization: A case study in Quzhou county. Journal of environmental management, 269: 110797. https://10.1016/j.jenvman.2020.110797 
Figures
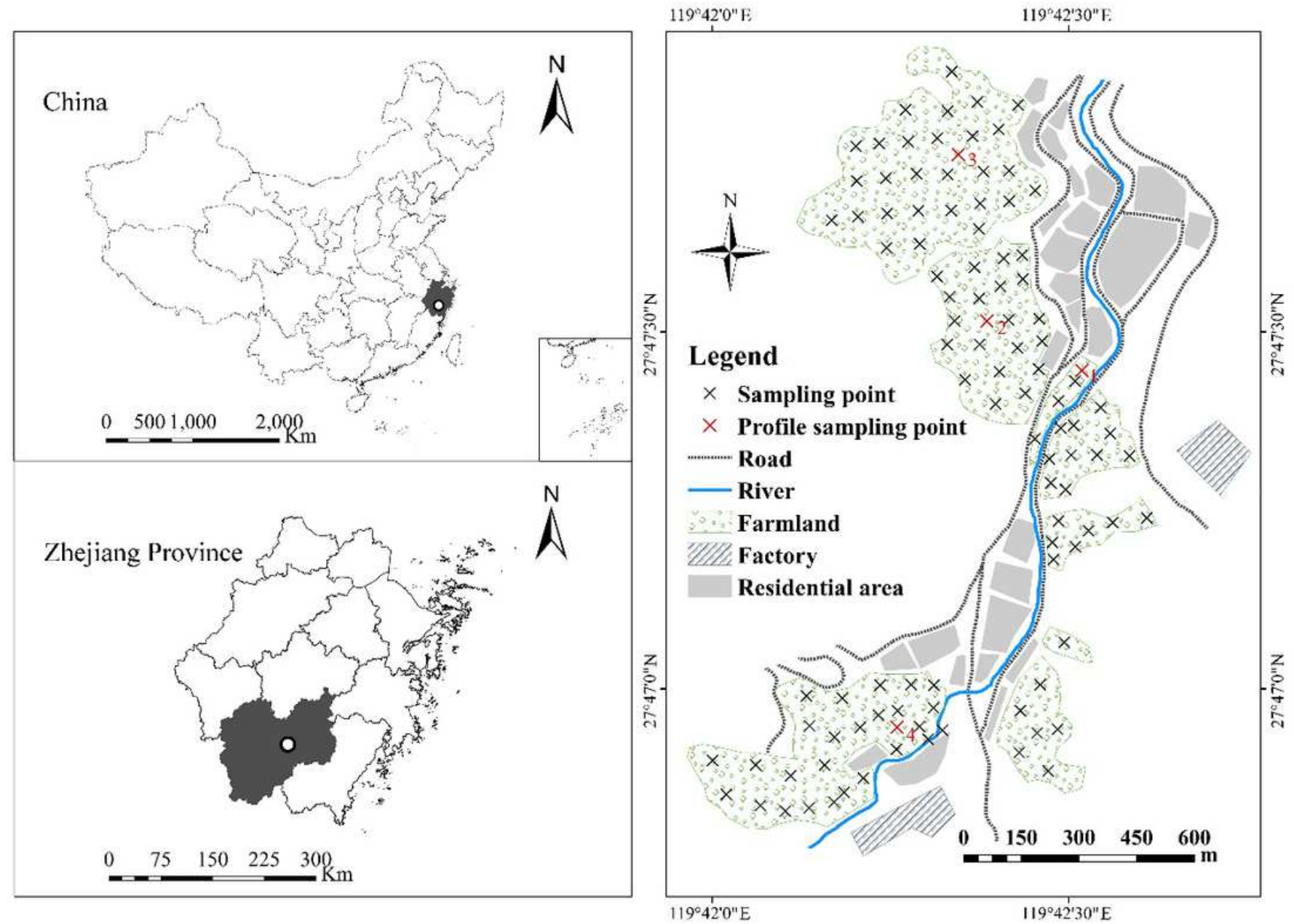

Figure 1

Distribution of sampling sites in the study area. 

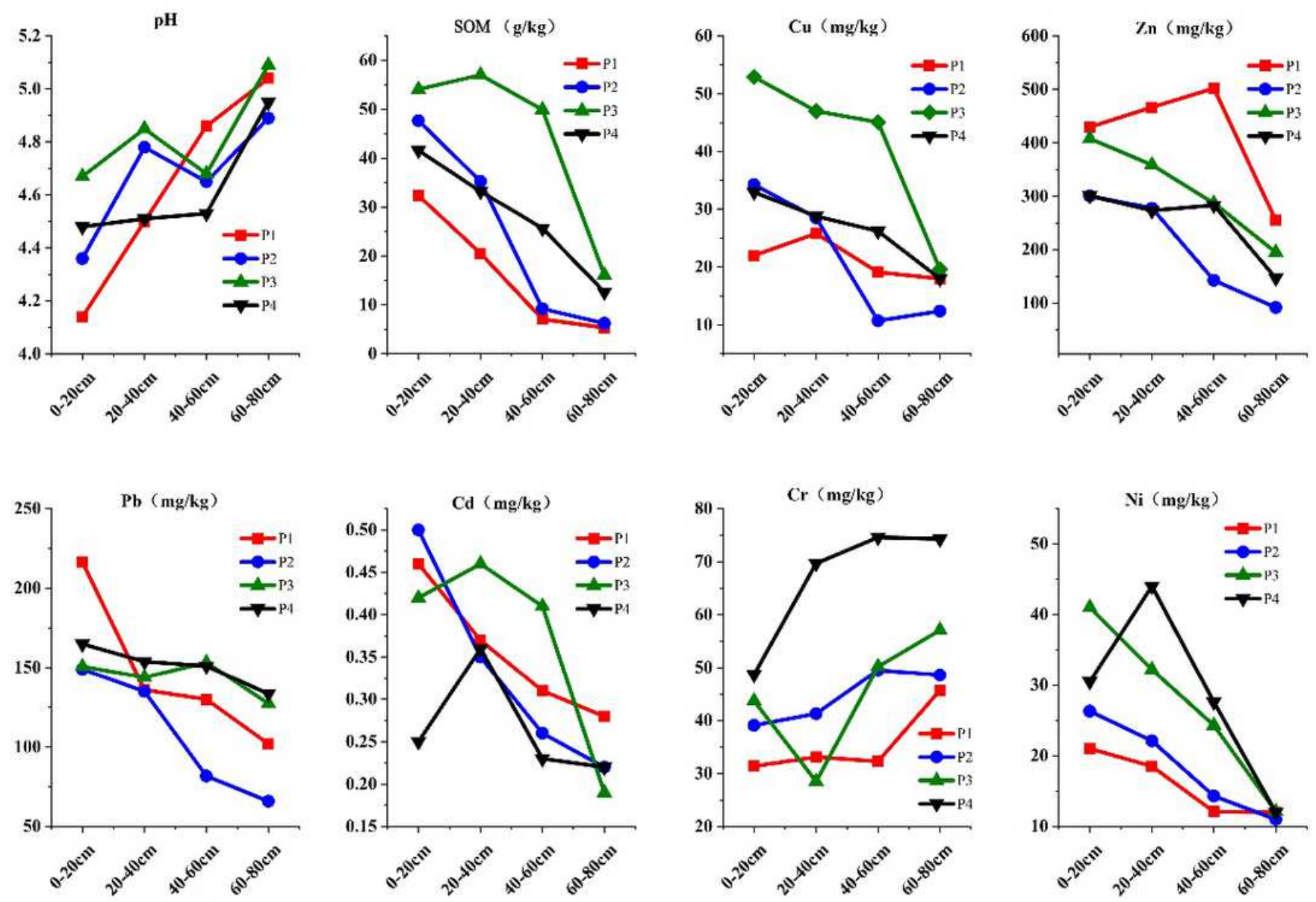

Figure 2

Distribution of heavy metals, $\mathrm{pH}$ and organic matter in soil profile 
(a) APCS-MLR

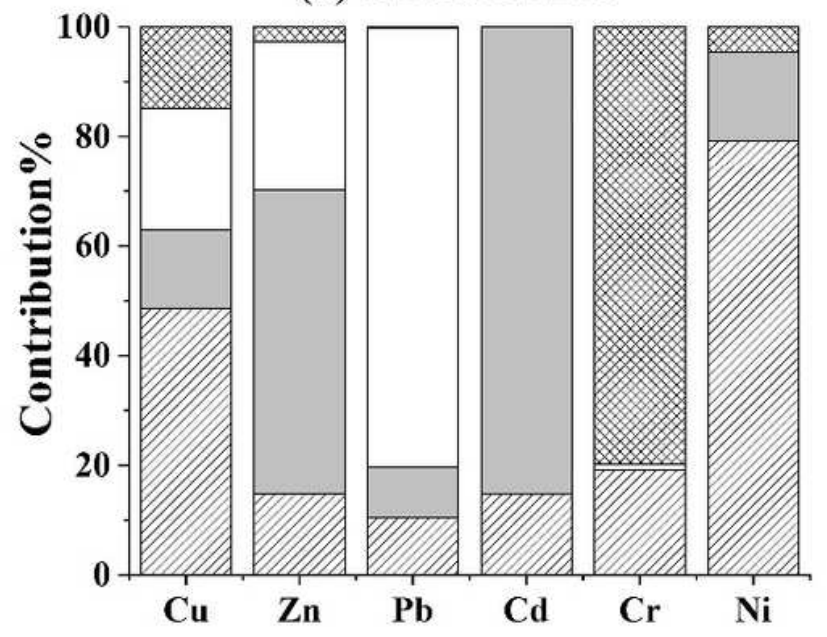

(c) PMF-1 Full data

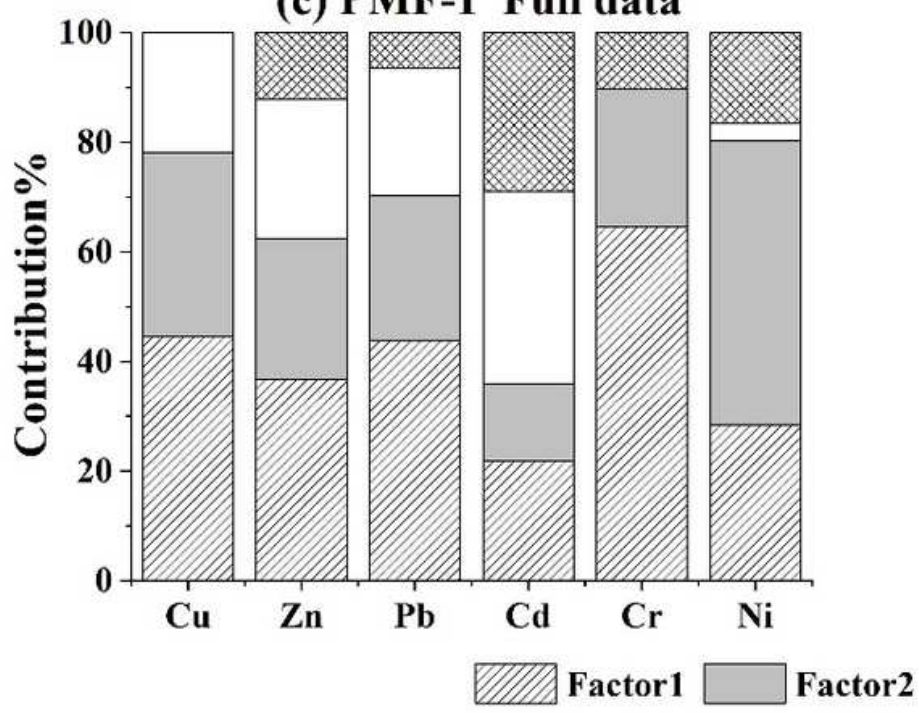

(b) UNMIX

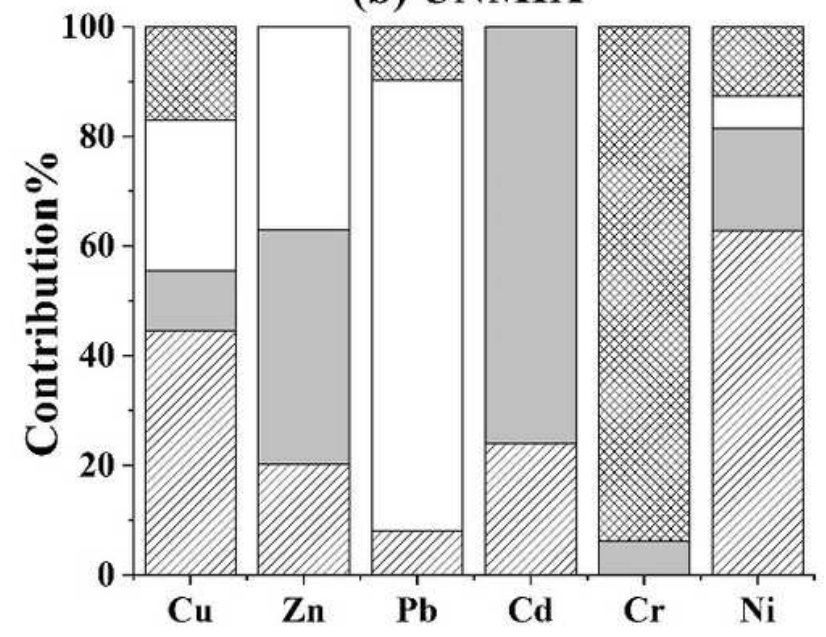

(d) PMF-2 Eliminates outliers

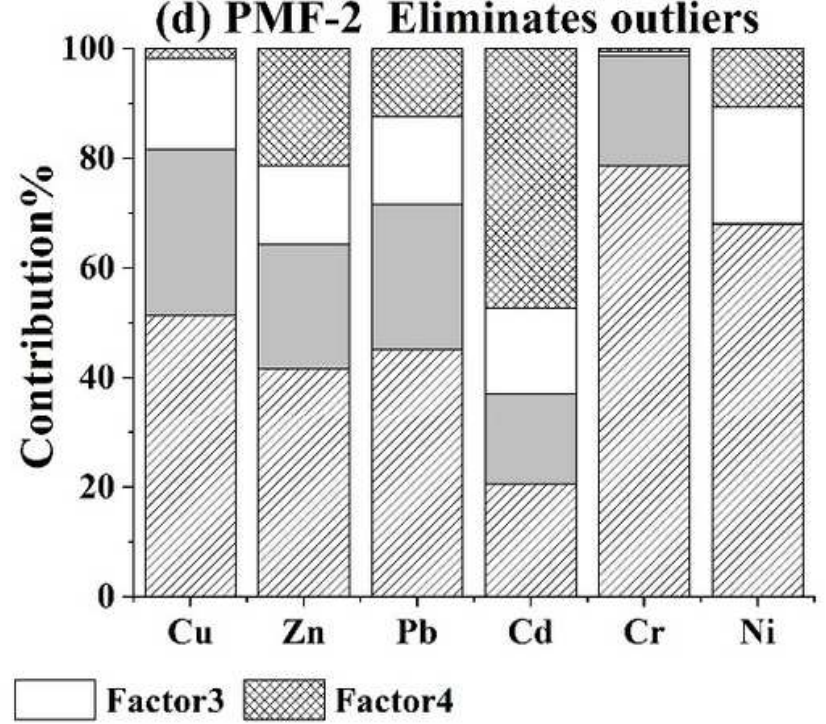

Figure 3

Source factor analysis of soil heavy metals in the study area 
(a) APCS-MLR

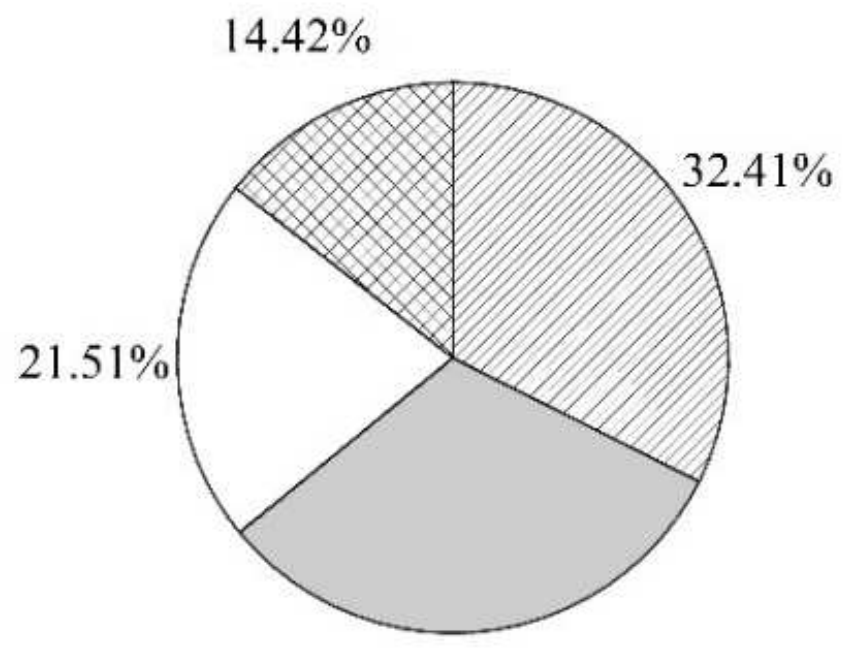

$31.65 \%$

(c) PMF-1 Full data

$$
10.06 \%
$$

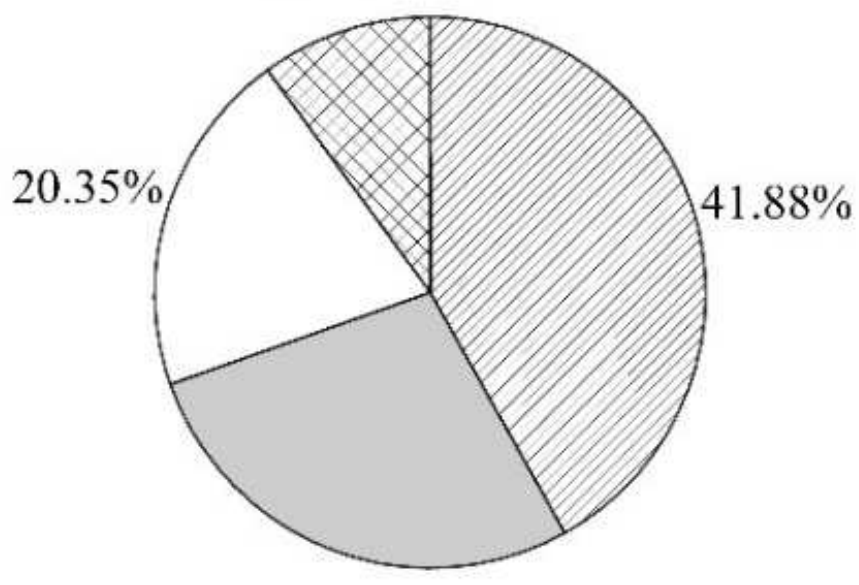

$27.7 \%$ (b) UNMIX

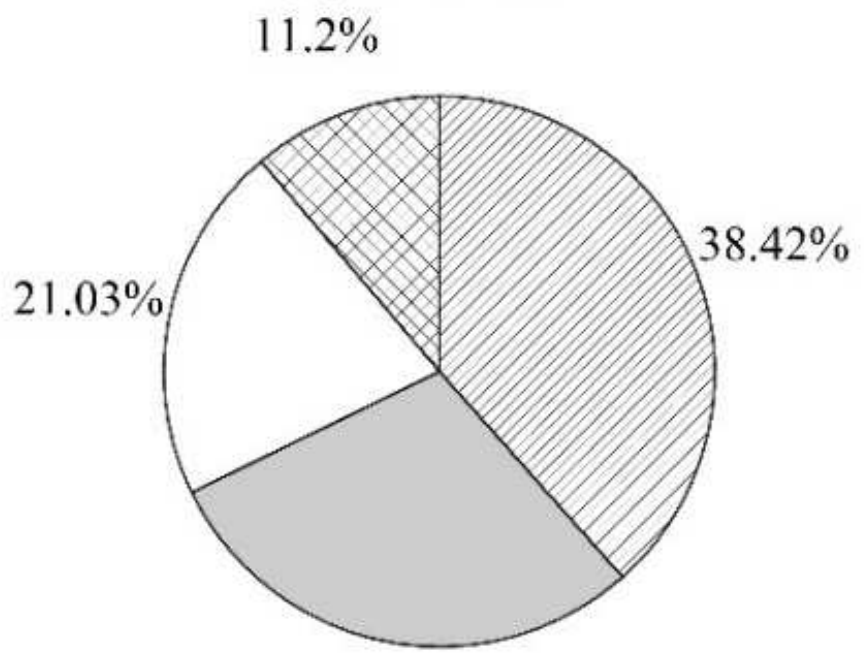

$29.35 \%$ (d) PMF-2 Eliminates outliers

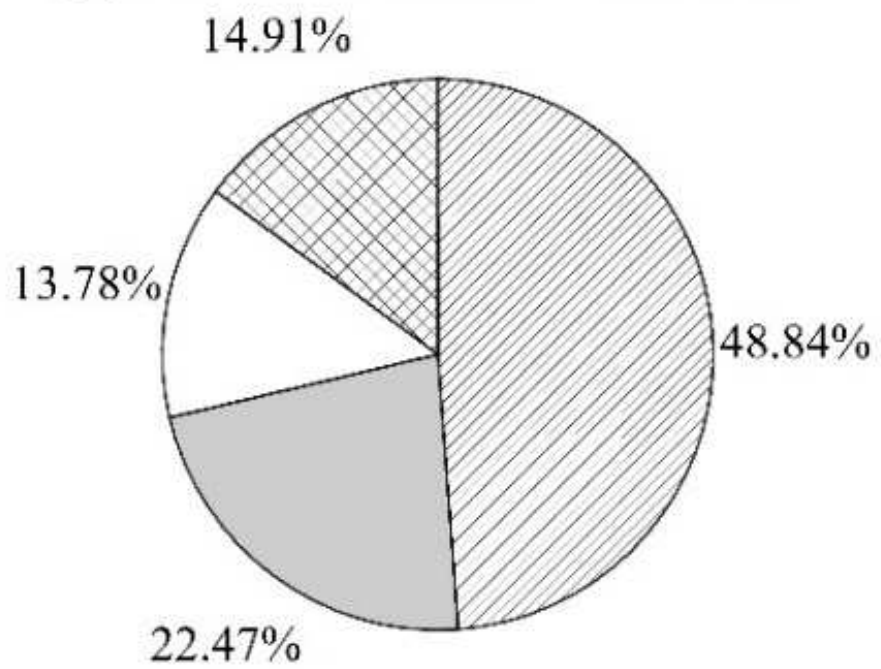

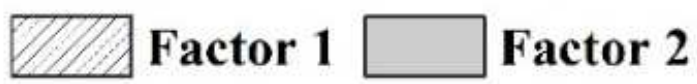

\section{Figure 4}

Factor contribution analysis of APCS-MLR, UNMIX and PMF models 